Немеханические процедуры делятся на физические (например, термолиз, осмотический шок, СВЧ), химические и ферментативные (в том числе автолиз) методы [4].

В настоящем исследовании для получения бета-глюкана нами использовались хлебопекарные прессованные и сухие активные дрожжи вида Saccharomyces cerevisiae. Изучена дезинтеграция клеток такими методами, как обработка 1 н раствором щелочи, 24 \% раствором перекиси водорода, ультразвуком, СВЧизлучением и индуцированный автолиз. Результаты дезинтеграции оценивались визуально с помощью микроскопирования и по количественному выходу бетаглюкана. Наиболее перспективным методом считаем метод обработки дрожжей СВЧ-излучением (выход технического бета-глюкана - 18,98 \%). Все полученные образцы бета-глюкана исследованы химическими (качественные реакции на примеси) и физическими методами (ИК-спектрометрия и ЯМР-спектроскопия). Проведенные исследования подтвердили, что выделенные продукты имеют структуру бета-(1-3), (1-6)-глюкана, содержащего незначительное количество примесей белков и аминокислот.

В перспективе планируется разработать метод выделения бета-глюкана из отработанных пивных дрожжей и использовать его в качестве БАД при получении функциональных молочнокислых продуктов типа йогурт.

1. Беседнова Н.Н., Иванушко Л.А. и др., Антибиотики и химиотерапия, 2, 37-44 (2000).

2. Zhu F., Du B., Xu B., Food Hydrocolloids, 52, 275-288 (2016)

3. Petravic-Tominac V., Zechner-Krpan V. et al., Agriculturae Conspectus Scientificus, 75, 149-158 (2010)

4. Bzducha-Wrobel A., Blazejak S. et al., Molecules, 19, 20941-20961 (2014).

\title{
STOCHASTIC MULTIMODAL OSCILLATIONS IN NONLINEAR BIOCHEMICAL MODEL
}

\author{
Bashkirtseva I.A., Zaitseva S.S.* \\ Ural Federal University, Ekaterinburg, Russia \\ *E-mail: svs.zaitceva@gmail.com
}

\begin{abstract}
We consider the influence of random noise on the dynamic regimes of one nonlinear biochemical model. The model admits either mono- or bistable zones. In the monostable zone stochastic excitability arise resulting in large-amplitude oscillations. In the bistable zone noise-induced transitions between the attractors are of interest. For a constructive research of these phenomena, we apply a theoretical approach using confidence domains method and stochastic sensitivity analysis.
\end{abstract}


We examine a stochastic version of the two-dimensional biochemical model proposed by Goldbeter $[1,2]$ :

where

$$
\begin{aligned}
& \frac{d x}{d t}=v+\psi(y)-\sigma \varphi(x, y)+\varepsilon \xi(t), \\
& \frac{d y}{d t}=\sigma \varphi(x, y)-\psi(y)-k y,
\end{aligned}
$$

$$
\begin{gathered}
\varphi(x, y)=\frac{x(1+x)(1+y)^{2}}{L+(1+x)^{2}(1+y)^{2}}, \\
\psi(y)=\frac{s y^{4}}{K^{4}+y^{4}} .
\end{gathered}
$$

Here $\xi(t)$ is a standart Gaussian white noise, and $\varepsilon$ is a noise intensity. The model describes a product-activated enzyme reaction with recycling of product $x$ into substrate $y$. We analyze the system behavior in two qualitatively different dynamic domains: a monostable zone where the system possesses a single attractor - stable equilibrium, and a bistable zone with two attractors - stable equilibrium and limit cycle.

The phenomenon of noise-induced excitability is an important property of the model. Solutions of the system switch from small-amplitude fluctuations to large-amplitude oscillations in the zone of stable equilibria as a result of stochastic forcing.

The bistability leads the system to complex multimodal oscillations due to the influence of random noise. Stochastic trajectories pass from one stable attractor to another depending on a measure of responsivity of the attractor to noise.

For a theoretical analysis of these qualitative phenomena, we employ a technique [3] that takes into consideration both particular features of a stochastic sensitivity of the attractors and geometrical properties of a random trajectories arrangement. Using this technique, we can predict and constructively examine noise-induced transitions between the attractors and stochastic excitement.

The work was supported by Russian Science Foundation (№16-11-10098).

1. Goldbeter A., Moran F., Biophys. Chem., 20, 149-156 (1984).

2. Goldbeter A., Moran F., Eur. Biophys. J, 15, 277-187 (1988).

3. Башкирцева И., Зайцева С., Вестник Удмуртского Универсистета. Математика. Механика. Компьютерные науки, 28, 3-14 (2018). 